\title{
A Comparative Study of Iran's TEFL and English Translation UEEs: Do High-stakes Tests Assess Critical Thinking?
}

\author{
Gerannaz Zamani \\ Department of English, Razi University, Kermanshah, Iran \\ Reza Rezvani \\ Department of English, Yasouj University, Yasouj, Iran
}

\begin{abstract}
Tests that require intellectual work and critical thinking increase students' achievement as well as motivation. The University Entrance Exams (UEEs) in Iran which are multiple-choice high-stakes tests and are primarily designed to screen the candidates for postgraduate studies are no exception. This paper aims at comparatively investigating Iran's MA (Master's of Art) UEEs of TEFL (Teaching English as a Foreign Language) and English translation through the use of Anderson and Krathwohl's (2001) taxonomy of the cognitive domain. With this aim, the (2007-2011) TEFL and English translation UEE test items of the technical knowledge sections were content analyzed in terms of the taxonomy of educational objectives using a detailed checklist developed based on the respective classification of cognitive objectives. The findings showed slight differences between TEFL and English translation UEEs in terms of critical thinking skills. The English translation test items pertained to critical cognitive skills in general and evaluation in particular to a larger extent. On the whole, the degree of critical thinking skills in the TEFL and English translation UEEs were not so desirable and the majority of the test items revealed lower-order thinking skills. Therefore, it is necessary to both reconsider teaching process and to promote critical thinking skills in constructing test items.
\end{abstract}

Index Terms - taxonomy of the cognitive domain, critical thinking, higher-order thinking skills, high-stakes tests

\section{INTRODUCTION}

Critical thinking is generally used as an umbrella term for variously defined discourse of higher-order thinking; the definitional literature base is broad (Pithers, 2000). Interchangeably used with terms such as problem solving, decisionmaking, informal logic or reasoning, and creative thinking, critical thinking is commonly referenced with contextdependent understanding (Facione, 1990; Gibson, 1995). Based upon expert consensus statements that arose from a paneled discussion of philosophers, educators, and scientists, Facione (1990) stated that critical thinking integrates cognitive skills and affective dispositions. The cognitive skills that are required for critical thinking are evaluation, analysis, interpretation, inference, explanation and self-regulation. Among the thinking skills, analysis, evaluation and inference are considered core skills and with increased proficiency of these skills, one is considered adept at critical thinking.

Critical thinking is not a body of knowledge itself; though having domain-specific knowledge allows a person to make reasonable judgments in specific contexts successfully. Reasonably, it is a purposeful application of thinking strategies within a body of knowledge or experience to arrive at a conclusion (Facione, 1990). In addition to being proficient in a specific skill, one must have the ability to use the skill even if it is not needed at the moment as well; this is termed affective disposition. These attitudes and habits of mind work together with cognitive skills to form a critical thinker. Instances of affective dispositions include being habitually disposed to engage in critical judgment, being able to make that judgment in multiple contexts for a variety of purposes, contributing to fair-minded analysis and decisionmaking, and promoting intellectual freedom in order to advance carefully reasoned investigations into any matter of social concern (Facione, 1990. p. 24).

The most general and recent of approaches to critical thinking is Anderson and Krathwohl's (2001) division of learning including learning for recall and learning for transfer. Teaching for transfer, enables students not only to remember and understand but also to use knowledge in more complex ways (Anderson \& Krathwohl, 2001). According to Anderson and Krathwohl (2001), a taxonomy can provide a wide range of important learning objectives and cognitive skills that students need to attain. For any content domain, students should know some concepts and facts and in some way be able to think and reason with these facts and concepts as well. Every time students solve new problems with their knowledge, they are transferring and transforming what they learned, and their understanding increases (Anderson \& Krathwohl, 2001). 
Studies have revealed that holding students accountable for higher-order thinking by using assessments that entail critical thinking and intellectual work increases students' achievement as well as motivation. Such increases have been revealed on various achievement outcomes, comprising classroom grades, standardized test scores, and research instruments, as the following studies illustrate.

Meece and Miller (1999) studied elementary students' goal orientations, strategy use and perceived competence in reading and writing. Throughout the research project, some of the 3rd grade teachers stated that their students did well in their skills and strategies on reading and writing tests but could not transfer those skills to actual reading and writing beyond the tests. After evaluating the 3rd grade assignments they found that most of the students focused on skills like recall, and teacher control.

In a study conducted by the National Assessment of Educational Progress (NAEP), assessments were given to a range of students. These assessments were derived from samples of students in the 4th, 8th, and 12th grades throughout the United States (U.S. Department of Education, 2001). In the study of these test scores, Wenglinsky found that teaching critical thinking is associated with higher test scores (Wenglinsky, 2000, 2002, 2003). Wenglinsky stated that, "instruction emphasizing advanced reasoning skills promotes high student performance" (Wenglinsky, 2004).

A study by Athari, Sharif, Nematbakhsh and Babamohammadi (2009) was conducted to evaluate critical thinking skills and its connection with the achieved rank in university entrance exam in the students of Isfahan University of Medical Sciences. In the academic year of 2006-2007, 89 students who entered Isfahan University of Medical Sciences were randomly selected, and their critical thinking skills were evaluated. The data was gathered using California standard test of critical thinking skills. The scores obtained were regarded as criteria for students' critical thinking skills and were investigated considering their relationship with the students' ranks in university entrance exam. The results showed that there was no significant relationship between the rank in university entrance exam and the overall score of critical thinking. Concerning the categories of critical thinking, there was a significant relationship between the category of inference and student's rank in the entrance exam, with a relatively low correlation. Except for the study mentioned, most studies conducted in Iran were focused on evaluating English textbooks using Bloom's cognitive taxonomy. For example, Riazi and Mosallanejad (2010), using Bloom's taxonomy of educational objectives, studied the types of learning objectives in high school and pre-university English textbooks in Iran. The researchers concluded that the most prevalent learning objectives in the textbooks were lower-order cognitive skills. To the best of the researchers' knowledge, the evaluation of higher-order thinking skills in high-stakes tests using Anderson and Krathwohl's (2001) cognitive taxonomy has been left largely untouched in Iran. Therefore, this paper is arguably a pioneering work which aims to probe into critical thinking skills in UEEs in terms of Anderson and Krathwohl's (2001) taxonomy of educational objectives.

\section{Cognitive Taxonomies}

Cognitive taxonomies are used for categorizing learning targets into different levels of complexity. Various taxonomies have been developed for classifying learning targets. Despite its age, the Taxonomy of Educational Objectives, Handbook I: Cognitive Domain (Bloom, Engelhart, Furst, Hill, \& Krathwohl, 1956) is still used in many curricula and teaching materials. Anderson and Krathwohl published a revision of the Bloom handbook in 2001. The main difference between the original and the revised taxonomy is that the revised version has two dimensionsKnowledge and Cognitive Process dimension. The Knowledge dimension categorizes the kind of knowledge students deal with: facts, concepts, procedures, or metacognition. The Cognitive Process dimension is very similar to Bloom's original taxonomy except that the nouns in the taxonomy are changed to verbs including Remember, Understand, Apply, Analyze, Evaluate and Create and the order of the last two levels is reversed.

Recently, Marzano and Kendall (2007), similar to Anderson and Krathwohl (2001), have distinguished knowledge from types of thinking. They identified three domains of knowledge: Information, Mental Procedures, and Psychomotor Procedures. Their thinking processes form a hierarchy of levels including: Retrieval, Comprehension, Analysis, Knowledge Utilization, Metacognition, and Self-System Thinking. Furthermore, the cognitive demands of many accountability tests are analyzed with Webb's (2002) Depth of Knowledge levels. Webb introduced four levels to categorize the cognitive processes required to do various cognitive activities: Recall and Reproduction, Skill and Concept, Strategic Thinking, and Extended Thinking.

What all these cognitive taxonomies obviously have in common is that as the cognitive levels get more complex, students must progressively deal with more pieces of information and more intricate relationships among them. Since Anderson and Krathwohl's(2001) cognitive taxonomy has been designed for analyzing and developing assessments, standards, and teaching, this paper seeks to examine UEE test items in terms of the Analyze, Evaluate, and Create levels (critical thinking skills) of the cognitive taxonomy.

\section{THE PRESENT STUDY}

The present paper attempts to compare the M.A. UEEs of TEFL and English translation of the academic years 20072011 in terms of critical thinking skills, i.e. Analysis, Evaluation and Creation. The evaluation took place with regard to the cognitive levels of Anderson and Krathwohl's (2001) cognitive taxonomy. To be more specific, the following research questions were raised:

a) Which of the cognitive skills are more prevalent in TEFL and English translation M.A.UEEs? 
b) How are critical thinking skills represented in TEFL and English translation M.A.UEEs?

c) How could the critical thinking skills in TEFL and English translation UEEs be compared?

\section{METHOD}

This study utilized qualitative content analysis, "a research method used for the subjective interpretation of the content of texts through the systematic classification process of coding and identifying themes or patterns" (Hsieh \& Shannon, 2005, p: 278). This process involved condensing raw data into categories based on valid inference and interpretation. Using a detailed checklist developed by the researchers based on Anderson and Krathwohl's (2001) cognitive taxonomy, the test items belonging to the specialized courses of TEFL and English translation M.A. UEEs of the years 2007-2011, were content analyzed and coded in terms of the cognitive processes. The frequency and percentage of the cognitive process in general and critical thinking skills in particular were then calculated. Since the nouns describe types of knowledge and the verbs the intended cognitive process, we examined the nouns and verbs in each question or exercise in relation to the cognitive process categories. Intra-rater reliability was measured by reanalyzing the standards three weeks after the initial analysis to ensure that they were placed in the correct cells in the taxonomy. The Kappa coefficient statistic proposed by Cohen (1960) was used to calculate intra-rater agreement. The values of Kappa Measure of Agreement for the TEFL and English translation standards were 0.80 and 0.85 respectively with a significance of $p<.0005$. The results were finally compared in order to determine if critical thinking skills differed in each field.

\section{INSTRUMENT}

An in-depth checklist was developed based on the respective classification of educational objectives by the researchers (see Appendix). This checklist comprises two sections: one section consists of the types of knowledge introduced by Anderson and Krathwohl which includes: Factual knowledge, Conceptual knowledge, Procedural knowledge, and Metacognitive knowledge. The other section is composed of the learning objectives; the six cognitive processes including: Remember, Understand, Apply, Analyze, Evaluate, and Create along with their sub-categories. The underlying continuum in the cognitive process dimension is cognitive complexity, ranging from low cognitive complexity in Remember to the highest cognitive complexity in Create. The dimensions form a two-dimensional Taxonomy Table with 24 cells. The six rows in the taxonomy table represent the main categories in the cognitive process dimension and the four columns depict the main categories in the knowledge dimension. The sub-categories in each dimension define the categories and were not used separately.

\section{M.A. TEFL and English translation UEEs}

Loschert (2000) describes high-stakes tests as assessments in which "students, teachers, administrators, and entire school systems must account for student performance" (p. 1). Tests that are used to make high-stakes decisions are normally standardized assessments, such as the university entrance examinations. The M.A. TEFL and English translation entrance exams which are held annually are both multiple choice tests composed of two sections. The first section which measures students' language proficiency includes grammar, vocabulary, and reading comprehension. The second part which is concerned with the purpose of this study is the technical knowledge test. Five sets of Iran's M.A. university entrance examination technical knowledge tests germane to the fields of TEFL and English translation from 2007 to 2011 were examined. Overall, the TEFL M.A. knowledge tests address three broad domains: (1) Teaching methodology, (2) Language testing, and (3) Linguistics. The technical part of the English translation M.A. tests contains items that measure five subject matters as: (1) Linguistics, (2) Lexicology, (3) Theories and principles of translation, (4) Contrastive analysis, and (5) Practice of translation. A description of the TEFL and English translation technical knowledge tests along with their codes is provided in Table 1.

TABLE 1

DESCRIPTION OF 2007- 2011 TEFL AND ENGLISH TRANSLATION UEE KNOWLEDGE TESTS

\begin{tabular}{|l|l|l|}
\hline $\begin{array}{l}\text { TEFL knowledge test } \\
\text { Domains }\end{array}$ & Number of tests & Codes \\
\hline Methodology & 180 & M (1-170) \\
\hline Language Testing & 90 & T (1-85) \\
\hline Linguistics & 90 & L (1-85) \\
\hline Total & $\underline{360}$ & \\
\hline $\begin{array}{l}\text { English Translation } \\
\text { Knowledge test domains }\end{array}$ & & \\
\hline $\begin{array}{l}\text { Theories and principles } \\
\text { of translation }\end{array}$ & 115 & TT (1-115) \\
\hline Linguistics & 60 & L (1-60) \\
\hline Contrastive analysis & 55 & CA (1-55) \\
\hline Lexicology & 55 & Le (1-55) \\
\hline Practice of translation & 35 & PT (1-35) \\
\hline Total & $\underline{320}$ & \\
\hline
\end{tabular}




\section{RESULTS OF THE STUDY}

The TEFL and English translation UEEs yielded mixed results concerning critical thinking skills. It seems that some tests contain questions asking students to think at a higher level, whereas others mostly assess lower-level knowledge material. After the analysis and classification of the test items of both fields in the taxonomy checklist, the following results were obtained.

\section{M.A. TEFL UEES}

Table 2 presents the cognitive demand and content in the technical knowledge tests of the $2007-2011$ entrance examinations including teaching methodology, language testing and linguistics. The majority of the test items assessed lower-order thinking skills at levels 1 and 2 (Remember and Understand) with the frequency of 51.2\% and 29.7\% respectively; in addition, test items focused on conceptual knowledge (59.4\%) to the largest extent.

TABLE 2

EDUCATIONAL OBJECTIVES IN TEFL 2007-2011ENTRANCE EXAMS

\begin{tabular}{|c|c|c|c|c|}
\hline \multicolumn{3}{|c|}{ Cognitive processes } & \multicolumn{2}{|l|}{ Types of knowledge } \\
\hline Remember & $51.2 \%$ & & Factual Knowledge & $36.4 \%$ \\
\hline Understand & $29.7 \%$ & $-83.7 \%$ & Conceptual knowledge & $59.4 \%$ \\
\hline Apply & $2.8 \%$ & & Procedural knowledge & $4.2 \%$ \\
\hline Analy ze & $11.6 \%$ & & Metacognitive knowledge & 0 \\
\hline Evaluate & $4.7 \%$ & $-16.3 \%$ & & \\
\hline Create & 0 & & & \\
\hline
\end{tabular}

Table 3 presents the percentage of the cognitive processes that were targeted in each technical knowledge test domain.

TABLE 3

COGNITIVE PROCESSES IN TEFL TECHNICAL KNOWLEDGE TEST DOMAINS

\begin{tabular}{|l|l|l|l|l|l|l|}
\hline Domains & Remember & Understand & Apply & Analyze & Evaluate & Create \\
\hline Methodology & $58.3 \%$ & $32.3 \%$ & 0 & $7.7 \%$ & $1.7 \%$ & 0 \\
\hline Testing & $46.2 \%$ & $18.7 \%$ & $10.9 \%$ & $12.1 \%$ & $12.1 \%$ & 0 \\
\hline Linguistics & $41.6 \%$ & $35.9 \%$ & 0 & $19.1 \%$ & $3.4 \%$ & 0 \\
\hline
\end{tabular}

According to the Table, language testing was the only course which focused on the cognitive process Apply (10.9\%) and critical thinking skills $(24.2 \%)$ to the largest extent. This is due to the fact that some test items in the language testing course required mathematical computations. In addition, higher-order thinking skills were of concern by allocating $16.3 \%$ of the test items to these skills. For example, the following is a question selected from the language testing section:

\begin{tabular}{|ll|}
\hline Among the following, the most satisfactory reading test item is characterized by-------. \\
$\begin{array}{ll}1-\mathrm{D}=0.50, \mathrm{FV}=0.75, \mathrm{r}_{\mathrm{pb}}=0.25 & 2-\mathrm{D}=0.50, \mathrm{FV}=0.85, \mathrm{r}_{\mathrm{pb}}=0.60 \\
3-\mathrm{D}=0.65, \mathrm{FV}=0.50, \mathrm{r}_{\mathrm{pb}}=0.50 & 4-\mathrm{D}=0.75, \mathrm{FV}=0.45, \mathrm{r}_{\mathrm{pb}}=0.80\end{array}$ \\
\hline
\end{tabular}

This question is assessing students at the evaluation level of thinking. They must make judgment based on criteria and standards. If students who take this test are not taught how to answer critical thinking questions, then they'll be hard-pressed to deal with questions of this ilk. The type of knowledge required is conceptual since students must know the principles and structure of the satisfactory item. At the other end of the spectrum are those test items with questions asked at a very low level of thinking. The tests in the teaching methodology section were mainly of this type by allocating $58.3 \%$ of its test items to lower-order cognitive skills and only $9.4 \%$ was dedicated to critical thinking processes. For instance, consider this question from the teaching methodology section:

\begin{tabular}{|lll|}
\hline --:------is often cited as a factor leading to the insufficiency of error analysis. \\
\hline 1- Accuracy & 2- Avoidance & 3- Inter-language $\quad$ 4- Positive transfer \\
\hline
\end{tabular}

This particular question is asked at a very low level of Recall, that is, a student either knows it or doesn't. No amount of critical thinking is going to help with a question like this. A student needs to have a teacher instruct him or he has to read it in a book somewhere. Factual knowledge is needed to answer the question. That is to say, this item requires the knowledge of specific information. The critical thinking skill Analysis was mostly emphasized in the linguistics technical knowledge test section with the frequency of $19.1 \%$. An example of this kind from linguistics can be:

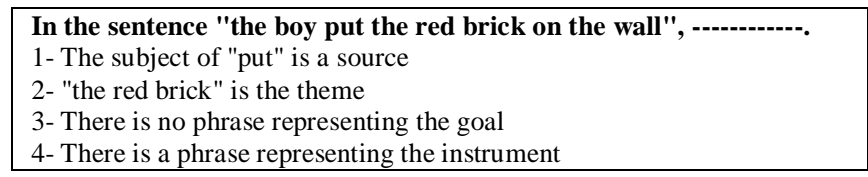


In this example, students need to break the statement into is constituent parts and determine how the parts are related to one another and to the overall structure. It involves differentiating and distinguishing the parts in terms of theta roles. This item involves conceptual knowledge. In other words, the student must know the interrelationships among the basic elements within the sentence.

On the whole, lower-order thinking skills (83.7\%) were the hotbed of TEFL UEE test items and merely $16.3 \%$ of the test items constituted critical thinking skills. Moreover, level 6, Create was totally absent in the exams.

\section{M.A. English translation UEEs}

Table 4 presents the cognitive demand and content of the knowledge tests pertaining to the English translation 20072011 UEEs. Similar to the TEFL exams, as it is clear in Table 4, the weight of emphasis was on lower-order thinking skills $(76.5 \%)$, whereas the English translation exams acknowledged the significance of critical cognitive skills (23.8\%) slightly more than the TEFL field.

TABLE 4

EDUCATIONAL OBJECTIVES IN ENGLISH TRANSLATION 2007-2011 ENTRANCE EXAMS

\begin{tabular}{|c|c|c|c|c|}
\hline \multicolumn{3}{|c|}{ Cognitive processes } & \multicolumn{2}{|l|}{ Types of knowle dge } \\
\hline Remember & $53.7 \%$ & & Factual Knowledge & $37.5 \%$ \\
\hline Understand & $22.8 \%$ & $\succ \quad 76.5 \%$ & Conceptual knowledge & $61.9 \%$ \\
\hline Apply & 0 & & Procedural knowledge & $0.6 \%$ \\
\hline Analyze & $10.6 \%$ & & Metacognitive knowledge & 0 \\
\hline Evaluate & $12.9 \%$ & $-23.5 \%$ & & \\
\hline Create & 0 & & & \\
\hline
\end{tabular}

The Apply and Create categories were completely ignored in the test items. Similar to TEFL conceptual knowledge, $61.9 \%$ constituted more than half of the test items. In addition, metacognitive knowledge was totally absent. The educational objectives in each technical knowledge test domain are presented in Table 5.

TABLE 5

EDUCATIONAL OBJECTIVES IN ENGLISH TRANSLATION KNOWLEDGE TEST DOMAINS

\begin{tabular}{|l|l|l|l|l|l|l|}
\hline Domains & Remember & Understand & Apply & Analyze & Evaluate & Create \\
\hline Lexicology & $25.4 \%$ & $36.4 \%$ & 0 & $38.2 \% \%$ & 0 & 0 \\
\hline $\begin{array}{l}\text { Practice of } \\
\text { Translation }\end{array}$ & $11.4 \%$ & 0 & 0 & 0 & $88.6 \%$ \\
\hline Linguistics & $65 \%$ & $21.7 \%$ & 0 & $8.3 \%$ & $5 \%$ & 0 \\
\hline $\begin{array}{l}\text { Theories and } \\
\text { Principles of } \\
\text { Translation }\end{array}$ & $77.4 \%$ & $20.8 \%$ & 0 & $0.9 \%$ & $0.9 \%$ \\
\hline $\begin{array}{l}\text { Contrastive } \\
\text { Analysis }\end{array}$ & $47.3 \%$ & $29.1 \%$ & 0 & $12.7 \%$ & $10.9 \%$ \\
\hline
\end{tabular}

As evident in Table 5, it is important to note the frequency of occurrence of Evaluate (88.6\%) which is central to critical thinking, in the practice of translation domain, while it was totally ignored and notoriously absent in the lexicology and theories and principles of translation. Lower-order thinking skills were more prevalent in tests pertaining to theories and principles of translation $(98.2 \%)$.

It is commonly believed that translation process is a complex thinking process (Neubert, 1991; Shreve \& Koby, 2003; Dimitrova, 2005). If students are to translate proficiently, they should learn how to think efficiently when translating. The test items on the practice of translation section were all of the same type requiring students to choose the most appropriate English or Persian translation. In such questions students should make judgments based on specific criteria such as the quality of translated statements in terms of the vocabulary selected, structure, literary devices, etc. Thus, such test items fall into the fifth level of the taxonomy, which is Evaluate. The contrastive analysis part was also concerned with the higher-order thinking skills Analysis (12.7\%) and Evaluate (10.9\%). The following example was taken from this part:

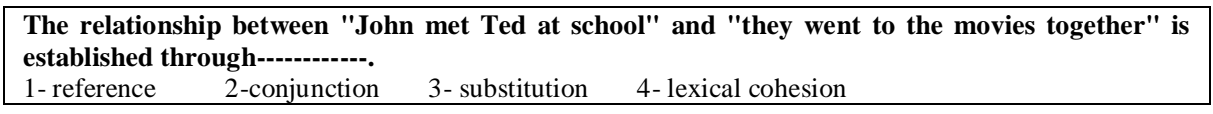

To answer this question a student needs to be able to analyze conceptual knowledge. The reader is to identify the elements of a situation and recognize how they relate to one another. Critical thinking skills would be beneficial for students taking tests of this nature. The Lexicology section included a large amount of analysis level test items (38.2\%). A number of test items required the analysis of lexeme constituent parts (affixes), such as the item below: 
ApPENDiX. ChECKList InCORPORATING The TAXONOMY OF EDUCATIONAL OBJECTIVES

\begin{tabular}{|c|c|c|c|c|}
\hline \multirow[b]{2}{*}{ Cognitive processes } & \multicolumn{4}{|c|}{ Types of Knowledge } \\
\hline & $\begin{array}{l}\text { Factual } \\
\text { knowledge }\end{array}$ & $\begin{array}{l}\text { Conceptual } \\
\text { knowledge }\end{array}$ & $\begin{array}{l}\text { Procedural } \\
\text { knowledge }\end{array}$ & $\begin{array}{l}\text { Metacognitive } \\
\text { knowledge }\end{array}$ \\
\hline \multicolumn{5}{|l|}{ Remember } \\
\hline \multicolumn{5}{|l|}{ 1- Recognizing pieces of information } \\
\hline \multicolumn{5}{|l|}{ 2- Recalling previous information } \\
\hline \multicolumn{5}{|l|}{ Understand } \\
\hline \multicolumn{5}{|l|}{ 1- Interpreting pieces of information } \\
\hline \multicolumn{5}{|l|}{$\begin{array}{l}\text { 2- Exemplifying, stating specific examples of a general } \\
\text { concept }\end{array}$} \\
\hline \multicolumn{5}{|l|}{ 3- Classifying information in to certain categories } \\
\hline \multicolumn{5}{|l|}{ 4- Summarizing an abstract or general theme } \\
\hline \multicolumn{5}{|l|}{ 5- Inferring and finding a pattern within a series of instances. } \\
\hline \multicolumn{5}{|l|}{ 6- Comparing and detecting the similarities and differences. } \\
\hline \multicolumn{5}{|l|}{ 7- Explaining and constructing a cause and effect model } \\
\hline \multicolumn{5}{|l|}{ Apply } \\
\hline \multicolumn{5}{|l|}{ 1- Executing and carrying out procedures on a familiar task } \\
\hline \multicolumn{5}{|l|}{$\begin{array}{l}\text { 2- Implementing and selecting a procedure to perform an } \\
\text { unfamiliar task }\end{array}$} \\
\hline \multicolumn{5}{|l|}{ Analyze } \\
\hline \multicolumn{5}{|l|}{$\begin{array}{l}\text { 1- Differentiating and discriminating information in terms of } \\
\text { relevance and importance }\end{array}$} \\
\hline \multicolumn{5}{|l|}{$\begin{array}{l}\text { 2- Organizing information and identifying how the elements } \\
\text { fit together into a coherent structure }\end{array}$} \\
\hline \multicolumn{5}{|l|}{ 3- Attributing, Knowing the intention underlying a message } \\
\hline \multicolumn{5}{|l|}{ Evaluate } \\
\hline \multicolumn{5}{|l|}{$\begin{array}{l}\text { 1- Checking and testing the inconsistencies and fallacies of } \\
\text { an operation or a product }\end{array}$} \\
\hline \multicolumn{5}{|l|}{$\begin{array}{l}\text { 2- Critiquing and judging an operation based on external } \\
\text { criteria }\end{array}$} \\
\hline \multicolumn{5}{|l|}{ Create } \\
\hline \multicolumn{5}{|l|}{ 1- Generating alternative solutions to a problem } \\
\hline \multicolumn{5}{|l|}{ 2- Planning or developing a plan to solve a problem } \\
\hline 3- Producing an carrying out a plan for solving a problem & & & & \\
\hline
\end{tabular}

\section{REFERENCES}

[1] Anderson L.W. (2005). Objectives, Evaluation, and the improvement of education. Studies in Educational Evaluation, (31), $102-113$.

[2] Anderson, L.W., \& Krathwohl, D. R. (2001). A taxonomy for learning, teaching, and assessing: A revision of Bloom's taxonomy of educational objectives. New York: Longman.

[3] Athari, Z., Sharif, M., Nematbakhsh, M., Babamohammadi, H. (2009). Evaluation of Critical Thinking Skills in Isfahan University of Medical Sciences' Students and Its Relationship with Their Rank in University Entrance Exam Rank. Iranian Journal of Medical Education, 9(1), 5-11.

[4] Bloom, B. S., Engelhart, M. D., Furst, E. J., Hill, W. H., \& Krathwohl, D. R. (1956). Taxonomy of educational objectives: The classification of educational goals. Handbook I: Cognitive domain. White Plains, NY: Longman.

[5] Cohen, J. (1960). A coefficient of agreement for nominal scales. Educational and Psychological Measurement, 20 , 37-46.

[6] Dimitrova, B. D. (2005). Expertise and Explicitation in Translation Process. Amsterdam Philadelphia: John Benjamins Publishing Company.

[7] Facione, P. A. (1990). Critical thinking: A statement of expert consensus for purposes of educational assessment and instruction: Research findings and recommendations. American Philosophical Association. ERIC Document Reproduction Service No. ED 315423.

[8] Gibson, C. (1995). Critical thinking: Implications for instruction. Reference \& User Services Quarterly (RQ), 35(1), 27-35.

[9] Hsieh, H.-F., \& Shannon, S.E. (2005). Three approaches to qualitative content analysis. Qualitative Health Research, 15(9), 1277-1288.

[10] Loschert, K. (2000). Raising the ante for students, teachers, and schools. Alexandria, VA: Association for Supervision and Curriculum Development. Retrieved November 4, 2002, from http:// www.ascd.org/frameinfobrief.html.

[11] Marzano, R. J., \& Kendall, J. S. (2007). The new taxonomy of educational objectives (2nd ed.). Thousand Oaks, CA: Sage.

[12] Meece, J. L., \& Miller, S. D. (1999). Changes in elementary school children's achievement goals for reading and writing: Results of a longitudinal and an intervention study. Scientific Studies of Reading, 3, 207-229.

[13] Neubert, A. (1991). "Models of Translation". In S. Tirkonnen-Condit (eds.). Empirical Research in Translation and Intercultural Studies. TÜbingen: Narr, 17-26.

[14] Pithers, R.T., \& Soden, R. (2000). Critical thinking in education: a review. Educational Research, 42(3), 237-249.

[15] Riazi, A.M., \& Mosalanejad, N. (2010). Evaluation of Learning Objectives in Iranian High- School and Pre-University English Textbooks Using Bloom's Taxonomy. TESL-EJ: The Electronic Journal for English as a Second Language. 13(4). 
[16] Shreve, G. \& G. S. Koby. (1997). "What's in the Black Box"? Cognitive Science and Translation Studies. In J. H. Danks, G. M. Shreve, S. B. Fountain and M. K. Mcbeath (eds.). Cognitive Process in Translation and Interpreting. Thousand Oaks: Sage Publications, xi-xviii.

[17] Webb, N. L. (2002). Alignment study in language arts, mathematics, science and social studies of state standards and assessments for four states. Washington, DC: Council of Chief State School Officers.

[18] Wenglinsky, H. (2004). Facts or critical thinking skills? What NAEP results say? Educational Leadership, 62(1), 32-35.

Gerannaz Zamani holds a B.A. in English Translation from Esfahan University, and an M.A. in TEFL from Yasouj University. She is now a PhD student of TEFL at Razi Kermanshah University. Her areas of interest are curriculum development/evaluation, testing and SLA.

Reza Rezvani received his BA (English Literature), MA and PhD (TEFL) from Shiraz University. He is currently a faculty member at the English Department of Yasouj University. His areas of interest are curriculum development/evaluation, translation and language assessment. 